\title{
Angiogenic properties of aged adipose derived mesenchymal stem cells after hypoxic conditioning
}

\author{
Anastasia Efimenko ${ }^{1}$, Ekaterina Starostina', Natalia Kalinina', Alexandra Stolzing ${ }^{2 *}$
}

\begin{abstract}
Background: Mesenchymal stem cells derived from adipose tissue (ADSC) are multipotent stem cells, originated from the vascular-stromal compartment of fat tissue. ADSC are used as an alternative cell source for many different cell therapies, however in ischemic cardiovascular diseases the therapeutic benefit was modest. One of the reasons could be the use of autologous aged ADSC, which recently were found to have impaired functions. We therefore analysed the effects of age on age markers and angiogenic properties of ADSC. Hypoxic conditioning was investigated as a form of angiogenic stimulation.
\end{abstract}

Methods: ADSC were harvested from young (1-3 month), adult (12 month) and aged (18-24 month) mice and cultured under normoxic (20\%) and hypoxic (1\%) conditions for $48 \mathrm{~h}$. Differences in proliferation, apoptosis and telomere length were assessed in addition to angiogenic properties of ADSC.

Results: Proliferation potential and telomere length were decreased in aged ADSC compared to young ADSC. Frequency of apoptotic cells was higher in aged ADSC. Gene expression of pro-angiogenic factors including vascular endothelial growth factor (VEGF), placental growth factor (PIGF) and hepatic growth factor (HGF) were down-regulated with age, which could be restored by hypoxia. Transforming growth factor (TGF- $\beta$ ) increased in the old ADSC but was reduced by hypoxia.

Expression of anti-angiogenic factors including thrombospondin-1 (TBS1) and plasminogen activator inhibitor-1 (PAI-1) did increase in old ADSC, but could be reduced by hypoxic stimulation. Endostatin (ENDS) was the highest in aged ADSC and was also down-regulated by hypoxia. We noted higher gene expression of proteases system factors like urokinase-type plasminogen activator receptor (UPAR), matrix metalloproteinases (MMP2 and MMP9) and PAI-1 in aged ADSC compared to young ADSC, but they decreased in old ADSC. Tube formation on matrigel was higher in the presence of conditioned medium from young ADSC in comparison to aged ADSC.

Conclusions: ADSC isolated from older animals show changes, including impaired proliferation and angiogenic stimulation. Angiogenic gene expression can be partially be improved by hypoxic preconditioning, however the effect is age-dependent. This supports the hypothesis that autologous ADSC from aged subjects might have an impaired therapeutic potential.

\section{Introduction}

Mesenchymal stem cells (MSC) have therapeutic potential in bone marrow transplantation [1,2], tissue engineering [3], and cell therapy [4]. Adipose-derived stem cells (ADSC) are relatively easy to obtain from adipose tissue and are more frequent than MSC in bone marrow [5].

\footnotetext{
* Correspondence: Alexandra.Stolzing@izi.fraunhofer.de

${ }^{2}$ Fraunhofer Institute for Cell Therapy and Immunology, Leipzig, Germany Full list of author information is available at the end of the article
}

They represent therefore a promising source for cell therapy, especially as their isolation is less invasive compared to bone marrow extractions and their expansion in culture is quite easy [6,7]. The use of MSC from aged bone marrow donors have been investigated and found to be less effective in myocardial infarction treatment in a mouse model probably because of age-induced changes [8]. For bone marrow derived MSC several studies analysed age-related changes [9] which were possibly responsible for the impaired therapeutic impact.

\section{() Biomed Central}


It is shown that ADSC are able to differentiate into the classical mesodermal tissues like bone, fat and cartilage [10], and it is claimed that they can differentiate into nerve, cardiomyocytes, hepatocytes and pancreatic cells $[11,12]$. ADSC show the same surface markers as bone marrow derived MSC $[13,14]$. For either cell type it is not clear if a small subpopulation of the MSC might contain additional differentiation capacity [15]. The in vivo potential of these cells is unclear, however support of neuronal repair [16], osteogenesis [17] and vasculogenesis were shown [18]. In some studies it was demonstrated that ADSC could release multiple angiogenic growth factors and cytokines/chemokines. This suggest that they may have potential as a useful cell source for therapeutic angiogenesis [19].

Upon in vitro expansion it was shown that ADSC age after about 30 population doublings [20] losing adipogenic differentiation capacity [21]. One group reported spontaneous transformation of ADSC. However no tumors were observed after injection of the cells into immune-compromised mice [22]. To minimise in vitro aging effects ADSC and other stem cells have been cultured under reduced oxygen concentrations with mixed results [23,24]. Differentiation of ADSC seems to be supported by higher oxygen levels and expansion by low oxygen levels [25].

Aging negatively affects angiogenesis which is found to be linked to declined levels of VEGF after ischemic stimuli [26]. Therefore, aging-associated changes may constitute a link to cardiovascular diseases and stroke in the elderly [27]. ADSC are thought to mediate angiogenesis by releasing growth factors including VEGF, HGF and basic fibroblast growth factor (bFGF). These factors stimulate endothelial cell division, migration, stromal progenitor cell grafting into the forming vessels. They also facilitate mobilization of bone marrow endothelial precursors which participate in neovascularization $[28,29]$. It is a matter of ongoing discussion whether this property is an important part of the regenerative mechanism of ADSC and is under investigation in several pre-clinical trials [30-33]. As angiogenesis seems to be an important factor in tissue remodelling in cell therapies we investigated the changes of the angiogenesis-related factor production in aged ADSC.

Hypoxia is known to stimulate the pro-angiogenic effects of ADSC [28,34], but little is known about the reactivity of aged ADSC upon a short term exposure to hypoxia. We therefore investigated ADSC from young and aged mice under low oxygen. The exact concentration of oxygen in adipose tissue is not known and we therefore used the levels of oxygen presumed for the bone marrow niche [24]. Proliferation and osteogenic differentiation was therefore tested for ADSC cultured under normoxia (20\%) or hypoxia (1\%) similar to levels found to be beneficial for bone marrow derived MSC.

\section{Materials and methods Chemicals}

All chemicals were obtained from Sigma-Aldrich unless stated otherwise.

\section{Isolation of adipose derived mesenchymal stem cells}

C57/Black6 mice were obtained from the University of Leipzig (Approval for schedule 1 sacrifices were given by the Regierungspräsidium Leipzig, Germany). ADSCs were isolated from adipose tissue of mice as described $[6,10,12]$. Adipose tissue was washed with PBS, minced and treated with $200 \mathrm{U} / \mathrm{ml}$ collagenase I in DMEM for $1 \mathrm{~h}$ at $37^{\circ} \mathrm{C}$. Tissue was centrifuged at $1200 \mathrm{~g}$ for $5 \mathrm{~min}$ and the supernatant discarded. The pellet containing the ADSC was lysed to destroy erythrocytes. The material was then filtered through a sieve, and washed. The cells were cultured at normoxic conditions ( $20 \%$ of oxygen) until the experiment starts.

\section{Hypoxia}

The day before hypoxia establishment the medium was replaced with serum-free medium. Then cells have been cultivated for $48 \mathrm{~h}$ under hypoxia ( $1 \%$ of oxygen) or normoxia (20\% of oxygen) conditions. Parameters of hypoxia modelling were chosen as the most favourable for inducing changes in gene expression in bone marrow derived MSC $[35,36]$. Cell properties were analyzed immediately after cells had been taken off the hypoxic incubator.

\section{Cell viability assessment}

The number of early apoptotic and dead cells was evaluated with flow cytometry by phycoerythrin conjugated annexin $\mathrm{V}$ (AnnexinV-PE) binding and 7-amino-actinomycin (7-AAD) dye accumulation. Cells were removed from culture plate surface by EDTA in PBS $(2 \mathrm{mM}, 5 \mathrm{~min}$, $\left.37^{\circ} \mathrm{C}\right) .100 \mu \mathrm{l}$ of cell suspension $\left(1-10 \times 10^{5}\right.$ cells $\left./ \mathrm{ml}\right)$ were incubated with AnnexinV-PE for 20 min and washed with buffer according to the manufacturing instructions. Then 7-AAD was added for $5 \mathrm{~min}$. Stained cells were analyzed with cell sorter MoFlo (Dako Cytomation). Cell number at various apoptosis stages $\left(\mathrm{AnnexinV}^{+} 7-\mathrm{AAD}^{-}\right)$and number of viable (AnnexinV $V^{-}$7-AAD ${ }^{-}$) and dead cells $\left(\mathrm{AnnexinV}^{+}\right.$ 7- $\left.\mathrm{AAD}^{+}\right)$were calculated.

\section{Immunophenotyping of ADSC}

Cells were harvested by trypsinisation and stained with antibodies against CD14, CD19, CD34, CD45, CD73, CD79, CD90, CD105, NG2 and PDGFRB (diluted 1:100; $4{ }^{\circ} \mathrm{C}$; $30 \mathrm{~min}$; Serotec, Oxford, UK). The cells were analysed using flow cytometry. $\mathrm{CD} 11 \mathrm{~b}$ antibody $\left(1: 100 ; 4^{\circ} \mathrm{C}\right.$; 
30 min; Serotec, Oxford, UK) was used as a negative control.

\section{Proliferation and osteogenic differentiation of ADSC} Cells were grown in 24 wells at 20,000 ADSC per well. Proliferation was measured using MTT test (Invitrogen). For osteogenic differentiation 40,000 ADSC were seeded in 24 well plates with medium containing $10^{-8} \mathrm{M}$ dexamethasone and $5 \mu \mathrm{g} / \mathrm{ml}$ ascorbic-2-phosphate for 14 days. Alkaline phosphatise (ALP) quantitation was performed using a colorimetric assay using $\rho$-nitrophenyl phosphate $(\rho$-NPP) as substrate [37]. Ethanol-fixed cells in 24-well plates were reacted with $200 \mu \mathrm{l}$ of ALP assay buffer $(5 \mathrm{mM}$ $\rho$-NPP, $0.5 \mathrm{mM} \mathrm{MgCl} 2,0.1 \%$ Triton X-100, and $50 \mathrm{mM}$ TBS, $\mathrm{pH}$ 9.5). After incubation at room temperature for $10 \mathrm{~min}$, the absorbance was measured at $405 \mathrm{~nm}$. The cells were washed, and cell number was determined.

\section{Reactive oxygen species (ROS) and nitric oxide (NO)} Cells were incubated in the dark with 5-(and-6)-chloromethyl-2,7-dichlorodihydrofluorescein diacetate acetyl ester $\left(\mathrm{H}_{2}\right.$ DCF-DA) $(50 \mu \mathrm{M})$ for $30 \mathrm{~min}$, washed and analysed with a flow cytometer. Nitric oxide concentration was measured using standard Griess reagent. $50 \mu \mathrm{l}$ supernatant was incubated with $50 \mu \mathrm{l}$ Griess reagent. After 5 min incubation at RT, the absorbance was measured at $560 \mathrm{~nm}$ using a tecan plate reader.

\section{Real-time PCR}

RNA was isolated according to instructions (RNA/DNA/ Protein Purification Kit, Norgen, Canada). RNA concentration was measured using the NanoDrop (Peqlab).
One $\mu \mathrm{g}$ of total RNA was used to synthesize cDNA with SuperscriptIII-transcriptase (70 U/1 $\mu \mathrm{g}$ RNA; Invitrogen) and Oligo(dT)18-Primers (Fermentas, see Table 1 for the different primer sequences used). For qRT-PCR (LightCycler 480, Roche) the cDNA was diluted 1:10 and $5 \mu \mathrm{l}$ added to Express SYBR GreenER qPCR Supermix Universal (Invitrogen) Serial dilutions of recombinant standard DNAs containing the analyzed gene sequences served as controls. Transcript amounts are normalized to GAPDH, 18S or L7.

\section{Quantitative telomerase activity assay}

Cell pellets were resuspended in lysis buffer and analyzed with qRT-PCR using the quantitative telomerase detection kit (QTD, Allied Biotech Inc.). Protein concentration was determined with the BCA Protein assay (Pierce). Assays were conducted with $1 \mu \mathrm{g}$ of cell extract, using $0,5 \mu \mathrm{M}$ telomerase primer TS (5'-AATCCGTCGAGCAGAGTT-3') and 0,5 $\mu \mathrm{M}$ anchored return primer ACX (5'-GCGCGG(CTTACC)3CTAACC-3') in $25 \mu \mathrm{l}$ using 12,5 $\mu$ l Express SYBR GreenER (Invitrogen). The mix was incubated for $30 \mathrm{~min}$ at RT and used in the qRTPCR. The threshold cycle value $(\mathrm{Ct})$ were determined from semi-log amplification plots and compared with a standard curve generated from serial dilution of telomerase positive HeLa cell extract. Telomerase activity was expressed relative to HeLa cells. The negative control was a heat control incubated for 15 minutes at $85^{\circ} \mathrm{C}$.

Telomere length measurement by quantitative PCR DNA was isolated using the above mentioned kit (Purification Kit, Norgen, Canada) and concentration was

Table 1 PCR primers used

\begin{tabular}{|c|c|c|}
\hline Gene & Sense strand & Antisense strand \\
\hline c-myc & AGTGCTGCATGAGGAGACAC & GGTTTGCCTCTTCTCCACAG \\
\hline p53 & TCCCCCGCAAAAGAAAA & CTGTAGCATGGGCATCCTIT \\
\hline oct-4 & ACATGAAAGCCCTGCAGAAG & AGATGGTGGTCTGGCTGAAC \\
\hline $18 \mathrm{~s}$ & CAGTAAGTGCGGGTCATAAGC & ATCCGAGGGCCTCACTAAAC \\
\hline VEGF-a & AGAGCAGAAGTCCCATGAAGTGA & TCAATCGGACGGCAGTAGCT \\
\hline PIGF & CCAAGGGGAAGAGGAAGAGGAGTA & GCAGGGACGAGTCGGCTAATAA \\
\hline bFGF & GCGCCGCCTTCCCACCAG & AGCCAGCAGCCGTCCATCTTCCT \\
\hline HGF & TCATTGGTAAAGGAGGCAGCTATA & CTGGCATTTGATGCCACTCTTA \\
\hline TGFb & TGCCCCTATATTTGGAGCCTGGAC & GCCCGGGTTGTGTTGGTTGTAGAG \\
\hline UPA & GAATGCGCCTGCTGTCC & AGGGTCGCTTCTGGTTGTC \\
\hline UPAR & CGTTACCTCGAGTGTGCGTCCTG & AGCCTCGGGTGTAGTCCTCATC \\
\hline MMP2 & AGTTCCCGTTCCGCTTCC & AGCCTCGGGTGTAGTCCTCATCC \\
\hline MMP9 & GCGGTGTGGGGCGAGGTG & CCAGGGGGAAAGGCGTGTGC \\
\hline ENDS & AGTTTGGTCTTGCTGCTGGTG & AAGTCCCGGAAGAAGAGTTTG \\
\hline TBS1 & GCGCGGAGCTGGATGTA & AATGTCTTCTGGGGTGGTTC \\
\hline PAl-1 & GCTTCATGCCCCACTTCTTCAA & ACCAGGCGTGTCAGCTCGTCTA \\
\hline L7 & CTCCGTCTGCGGCAGATC & CAGCATGTTAATTGAAGCCTTGTT \\
\hline GAPDH & GACCCCTTCATTGACCTCAACTAC & TGGTGGTGCAGGATGCATTGCTGA \\
\hline
\end{tabular}


measured using the nanodrop (Peqlap). Telomere length was measured and analyzed by qRT-PCR [38]. PCR was performed in a Light Cycler 480 (Roche).

\section{Carbonyl-ELISA}

Protein carbonyls were measured according to Buss et al. [39] with modifications described by Sitte et al. [40]. The absorbance was determined with a multiwell plate reader using a detection wavelength of $492 \mathrm{~nm}$.

\section{GpX activity}

Cells were lysed in a buffer and the proteins isolated. After measuring the protein concentration using BCA, GPX activity was measured according to instructions provided by the company (Cayman Chemical).

\section{In vitro tube formation assay}

Effect of young and aged ADSC conditioned medium in vitro on capillary-like tubes formation on Matrigel was evaluated. Conditioned medium was collected from ADSC of young (1.5-2 months old) and aged (18 months old) mice cultured in hypoxic and standard conditions. Human umbilical vein endothelial cells (HUVEC) at the 2-4th passages were seeded in 48-well plates coated with growth factor reduced Matrigel (BD Bioscience) in concentration $2 \times 10^{4}$ cells per well. HUVEC growth medium was supplemented with conditioned medium in ratio 1:1. At least, two wells were used for each sample of conditioned medium. HUVEC serum-free growth medium was utilized as negative control; HUVEC growth medium with 20\% FBS served as positive control. Plates were placed into $\mathrm{CO}_{2}$-incubator at $37^{\circ} \mathrm{C}$ and capillary-like structures were assayed in $24 \mathrm{~h}$ under the light microscope (Leica, Germany). Total length of tubular structures was counted in 5 random fields of view (objective 10x) with MetaMorph 5.0 software (Universal Imaging).

\section{Data analysis}

Statistical analysis was performed using SigmaStat 9.0. If normality of data was confirmed (according to the Shapiro-Wilkson test) comparison of independent groups was performed by Student t-test, if not - by one-way analysis of variance (Cruscal-Wolles ANOVA) and Mann-Whitney U-criteria. Multiple comparisons were made using Tukey's test. Values were expressed as mean + / - standard deviation for normally spread data and as median (25, 75 percentile) for not normal data. Data was considered significantly different when $\mathrm{p}<0.05$.

\section{Results}

\section{ADSC characteristics}

Analyzing of ADCS immunophenotype by flow cytometry showed that cells were positive for CD73 (83 $\pm 8 \%)$, CD90 (>95\%) and CD105 (>95\%) with no or low expression of CD14 (<10\%), CD19 (<10\%), CD34 (<5\%), CD45 (<1\%), CD79 (<10\%). This expression profile is normal for MSC according to the International Society for Cellular Therapy Statement of minimal criteria for defining MSC [41]. ADSC also expressed pericyte markers like neural glial antigen (NG2) and platelet derived growth factor receptor beta (PDGFRB), which stayed in agreement with a conception of this type of progenitors as perivascular cells (data not shown) $[42,43]$.

ADSC derived from young mice proliferated significantly faster than those from old mice (Figure 1a). Young ADSC under hypoxic conditions (1\%) proliferate significantly slower. Aged ADSC under hypoxic conditions did not decrease their proliferation rate (Figure 1a).

Measurements of annexin V binding and 7-AAD accumulation by flow cytometry showed that number of apoptotic cells was 3-fold higher in aged ADSC. Both young and aged ADSC cultivation under hypoxia neither induce cell death by apoptosis nor reduce their general viability (Figure $1 \mathrm{~b}$ ).

Cell senescence is accompanied with changes in cell cycle regulators. C-myc is found to be down-regulated in aged ADSC in normal and hypoxic treated cultures (Figure 1c). Surprisingly we find the same decrease in the expression pf p53 (Figure 1d). Analyzing the osteogenic differentiation of ADSC we showed that level of ALP per cell in ADSC cultured in osteogenic induction medium was higher in aged cells compared to young (Figure 2a).

We measured ROS and NO levels because they are both important signal molecules for osteogenic differentiation of ADSC and a marker of cell quality. ROS levels as well as NO production were significantly increased in aged ADSC (Figure 3a, b). The levels of ROS were significantly down-regulated in aged ADSC under hypoxic conditions; however they were not affected in young ADSC (Figure 3a).

Increasing oxidative stress is linked to induction of differentiation. We therefore measured therefore the level of the stemness gene oct 4 which is expressed in MSC. Aged ADSC oct 4 expression is significantly downregulated for normal but not for ADSC under hypoxia (Figure 2c).

The loss of proliferation due to age is often linked to telomere shortening in somatic cells. In ADSC we found a dramatic shortening of telomere length due to the age of the mice. The short term culturing under hypoxic conditions did not affect telomere length (Figure 2c). Increased ROS production might be linked to declining antioxidant activities. Therefore we measured the activity of glutathione peroxide (GPx) activity, arguably one of the most important antioxidative enzymes. GPx activity decreased with age in ADSC. In aged ADSC cultures 

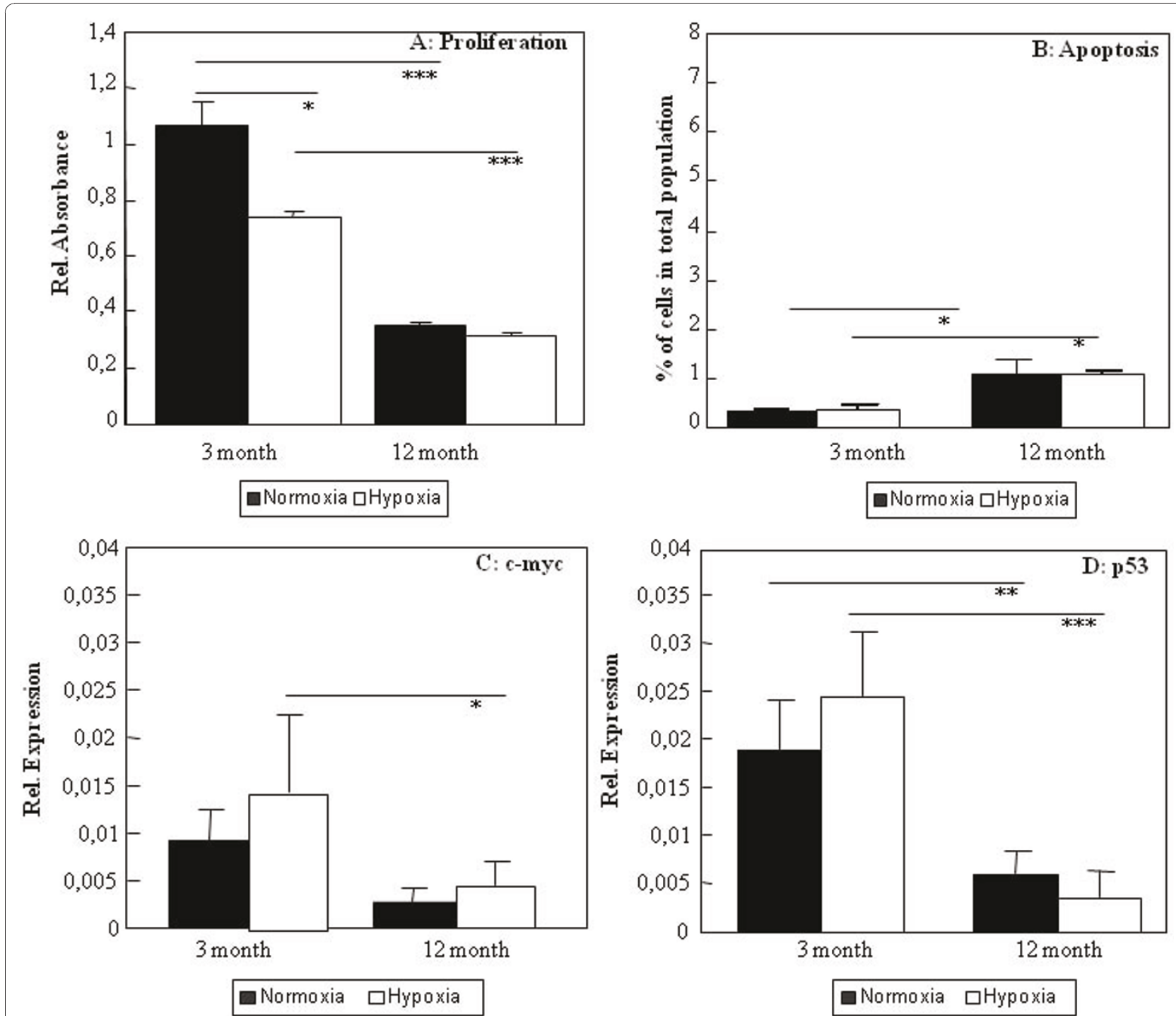

Figure 1 Proliferation and viability analysis of ADSC. Proliferation was measured in young and aged (12 month) ADSC cells cultured under normoxia or hypoxia for $48 \mathrm{~h}$ before the test (A). Level of cell death was measured using a double staining of 7-AAD and annexinV quantified by flow cytometry (B). Expression of c-myc (C) and p53 (D) were measured using qRT-PCR. Results are means of 5 different animals and considered significantly changed when: ${ }^{*}=p<0.05,{ }^{* *}=p<0.01,{ }^{* *}=p<0.001$

under hypoxic conditions the activity decreased even further (Figure 3c). Levels of carbonyls were significantly down-regulated in aged ADSC under normoxic and hypoxic conditions (Figure 3d). Interestingly we observed increased carbonyl levels in young ADSC but decreased carbonyl levels in aged ADSC under hypoxia.

\section{Angiogenesis}

Expression of several genes involved in angiogenesis was analysed in ADSC of different age. To evaluate the dynamic of age-changes in gene expression we included an additional group of 24 months old animals.

Gene expression of VEGF, a pro-angiogenic acting cytokine, declined significantly in ADSC from 24 month old mice and was unchanged in 18 month old mice compared to the 3 month old group. Hypoxia significantly stimulated the production of VEGF in all measured groups; however the effect declined with increasing age (Figure 4a).

PIGF, another pro-angiogenic factor, already was down-regulated significantly in ADSC from 18 month old mice and also in ADSC from 24 month old mice. Hypoxia increased mRNA content of PlGF in all groups. However the size of the changes induced by hypoxia in ADSC declined rapidly with age (Figure 4b).

Interestingly, gene expression of HGF, an important angiogenic and anti-apoptotic factor, was significantly higher in ADSC from 18 and 24 month old mice 


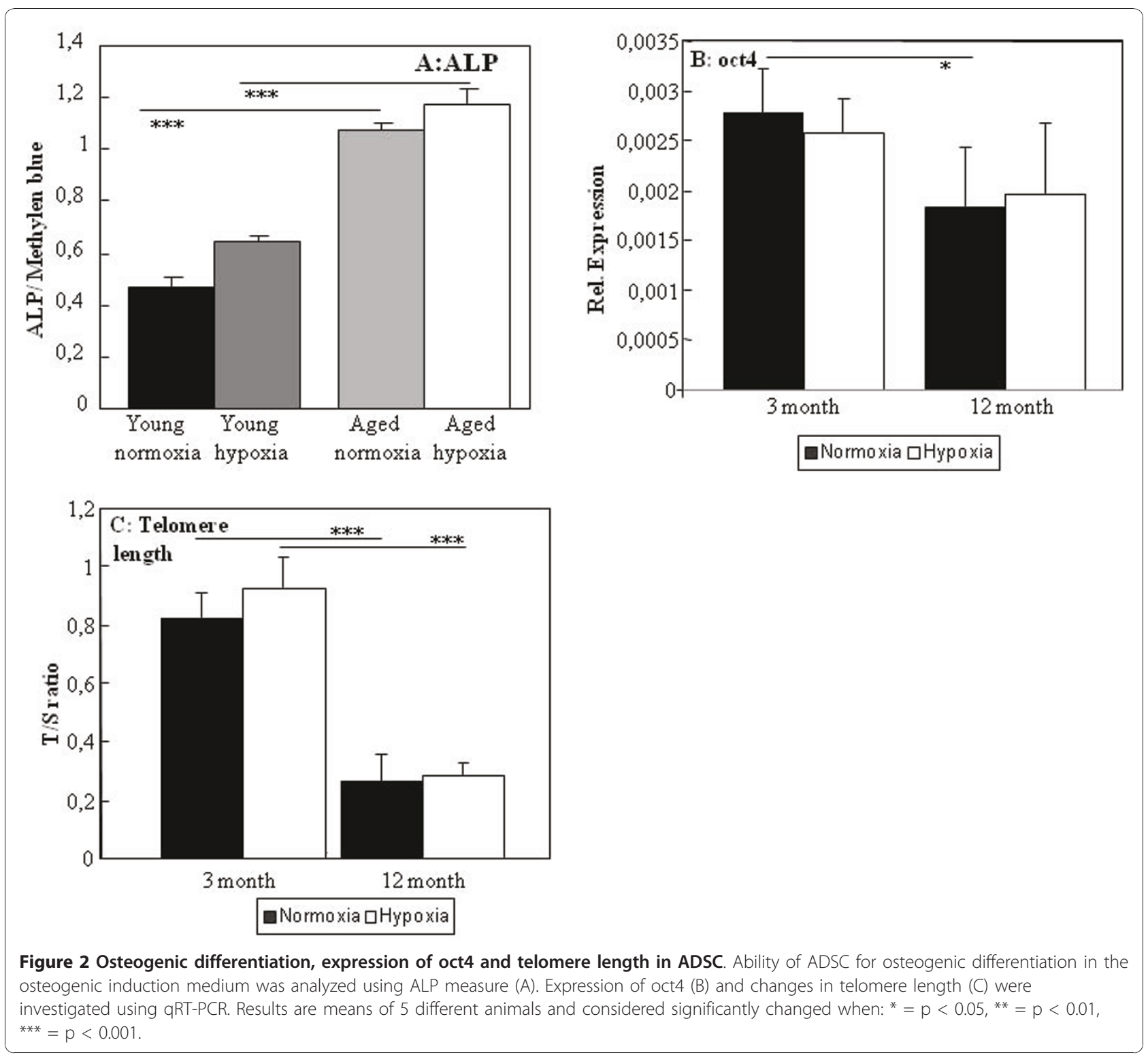

compared to young ADSC, but aged cells showed worse response to hypoxia, which resulted in the similar level of HGF in young and aged ADSC cultured under hypoxic conditions (Figure 4c).

Gene expression of TGF- $\beta_{1}$ were similar in ADSC from young and aged animals but did increase significantly in old ADSC (Figure 3d). Hypoxia did not alter expression levels in young or aged ADSC but declined TGF- $\beta_{1}$ expression in old ADSC.

Factors regulating migration and chemotaxis of stem cells like urokinase (UPA) and its receptor (UPAR) as well as MMPs are involved in angiogenesis by degrading the matrix. Expression of MMP2 and MMP9 significantly increased in aged ADSC (18 month old mice) compared to young ADSC but declined in old ADSC.
In hypoxic conditions MMPs expression level could be decreased significantly in young and aged ADSC but not in old ADSC (Figure 5a, b). uPAR expression significantly increased in aged ADSC and hypoxia stimulated its expression only in young ADSC (Figure 5c). uPA expression declined significantly in old ADSC compared to young ADSC. Hypoxia inhibited uPA expression in aged ADSC but this effect did not reach significance in young ADSC (Figure 5d). ADSC of the oldest group of mice did not react to the hypoxia stimulus (Figure 5).

Expression of anti-angiogenic factors, including PAI-1, ENDS and TBS1 was higher in aged ADSC compared to young ADSC, but the elevation was significant only for PAI-1. Cell culture under hypoxic conditions inhibited expression of all anti-angiogenic factors (Figure 6a, b, c). 


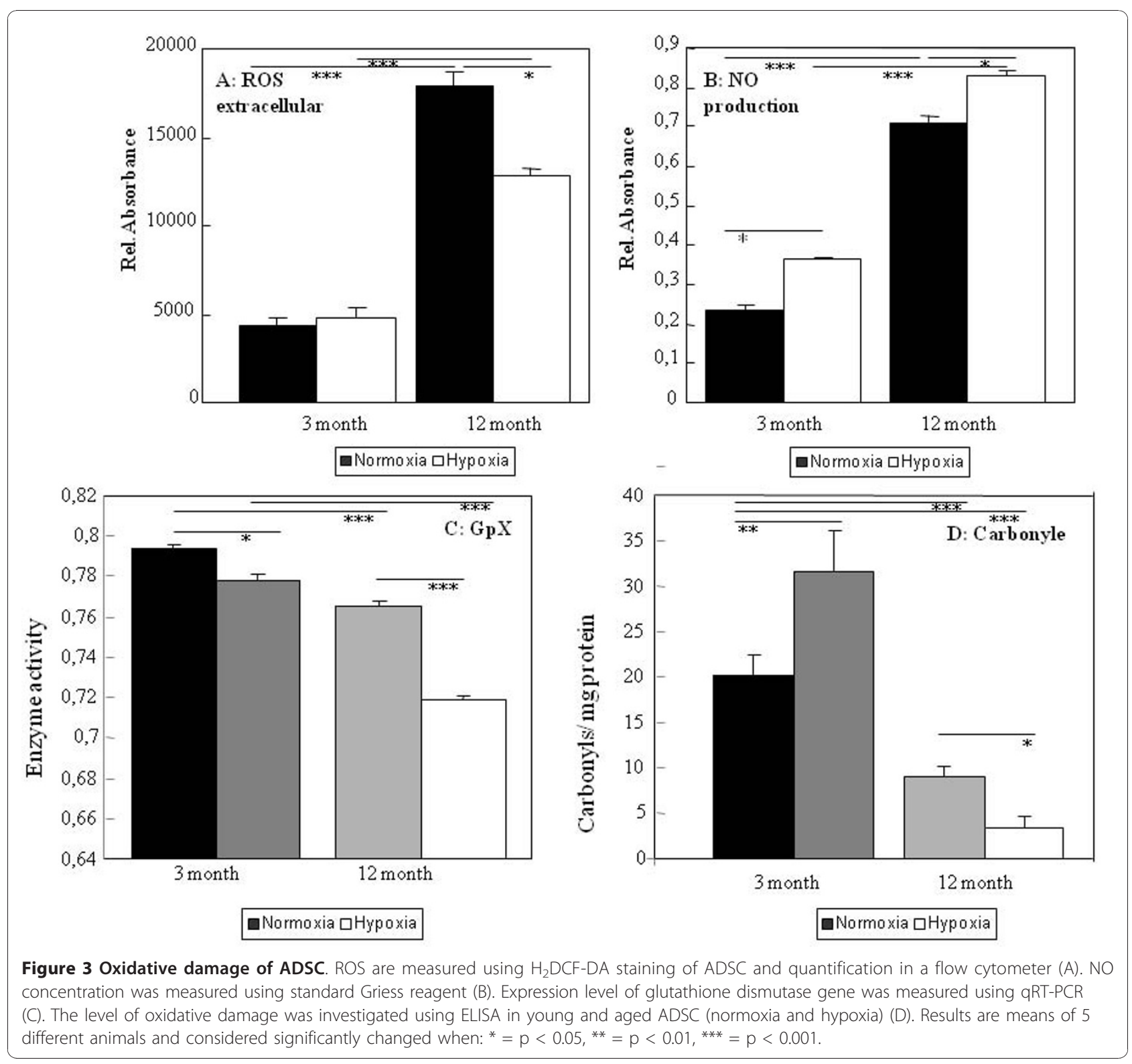

To evaluate the summary of angiogenic factors produced by ADSC we examined the effect of conditioned medium from cells cultured under different conditions on the capillary-like tube formation (Figure 7a, b). Tube formation assay showed that more extensive network of capillary-like structures on Matrigel was formed in the presence of conditioned medium from young ADSC as compared with aged ADSC $(\mathrm{p}=0.01)$. Conditioned medium from both types of cells cultured under hypoxia better stimulated formation of capillary-like structures than the medium from cells cultured under normoxic conditions $(\mathrm{p}=0.012$ for young $\operatorname{ADSC}$ and $\mathrm{p}=0.074$ for aged ADSC), but difference in this elevation between young and aged ADSC was insignificant $(13 \pm 3 \%$ for young ADSC vs. $11 \pm 4 \%$ for aged ADSC, $\mathrm{p}=0.49$ ).

\section{Discussion}

Adipose tissue derived MSC are a good alternative source to bone marrow derived MSC for cell therapy because of their easy access and high cell numbers. However they seem to undergo similar age-induced changes as bone marrow derived MSC [44]. Here we tested the effect of short-term hypoxic conditioning during cultivation of young and aged MSC from adipose tissue. Hypoxic conditioning has shown beneficial effects in bone marrow derived MSC, increasing their angiogenic properties [36].

We found more apoptotic cells among aged ADSC compared to young ADSC which is in agreement with higher ROS and NO production and down-regulation of antioxidative defence enzyme GPx in these cells. 

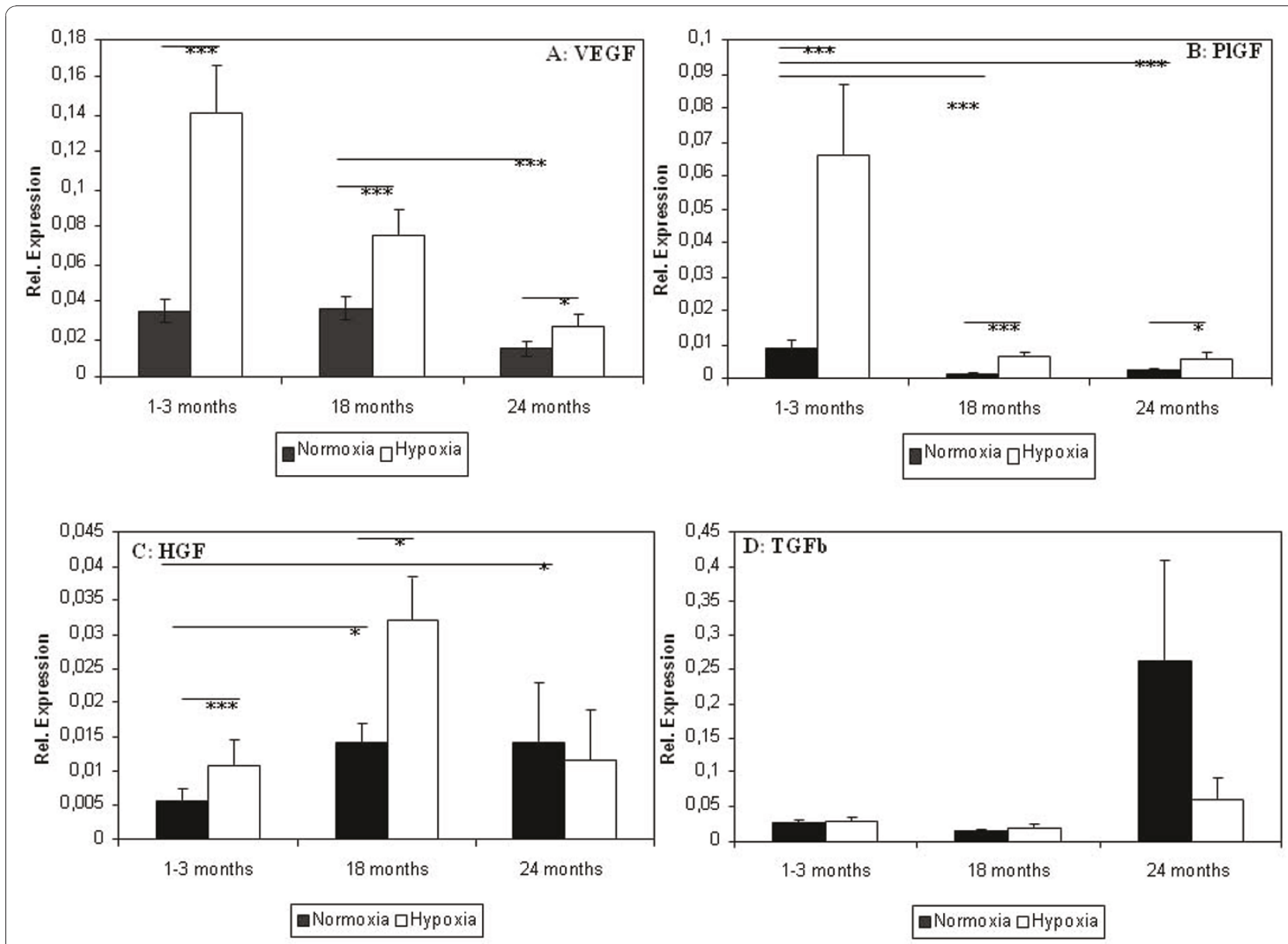

Figure 4 Effect of age and hypoxic stimulation on pro-angiogenic factors gene expression. Expression levels of VEGF (A), PGF (B), HGF (C) and TGF-beta (D) were measured using qRT-PCR. Animal groups consisted of young (1-3 month, 16 animals), aged (18 months, 9 animals) and old mice (24 months, 7 animals). Results are means of different animals $\left(*=p<0.05,{ }^{* *}=p<0.01,{ }^{* * *}=p<0.001\right.$ ).

In aged ADSC the mRNA expression level of p53 was down-regulated. On the contrary, in rat and human aged bone marrow derived MSC, we found an increased p53 protein content [44]. Other reported increased p53 gene expression levels in human aged bone marrow MSC [45]. Another factor involved in proliferation but also senescence is c-myc a tumor promoter gene. We found that in aged ADSC c-myc is down-regulated (Figure 1c) as it had been reported for other senescent cell types [46]. The third part of ADSC proliferation is the maintenance of self-renewal, and here we analysed Oct4 expression which is known to be expressed in undifferentiated MSC. We found a small reduction of Oct4 gene expression with age. A loss of stem cell characteristics has been described for MSC from different species and locations. Oct4 expression was also found to be down-regulated in aged mouse satellite stem cells and in hESC cells cultured with serum from old mice [47].
All of these features were accompanied with telomere shortening. This was also for human MSC derived from different age groups [48]. ADSC derived from aged mice showed reduced proliferation potential compared to young ADSC as it was also reported for MSC from bone marrow [44] and did not react to the lower oxygen as was observed for aged rat bone marrow derived MSC [23]. A similar loss of responsiveness to a culture stimulus was observed in aged bone marrow MSC towards a temperature change [49]. It seems that aged MSC are less able to adapt to environmental changes and lose a part of their stem cell potential.

\section{Angiogenesis during regeneration}

MSC can participate in regeneration via paracrine effects. MSC release different factors including growth factors, immune-modulatory factors and chemo-attractants involved in angiogenesis [50]. Angiogenesis is thought to be one of the mechanisms by which MSC 

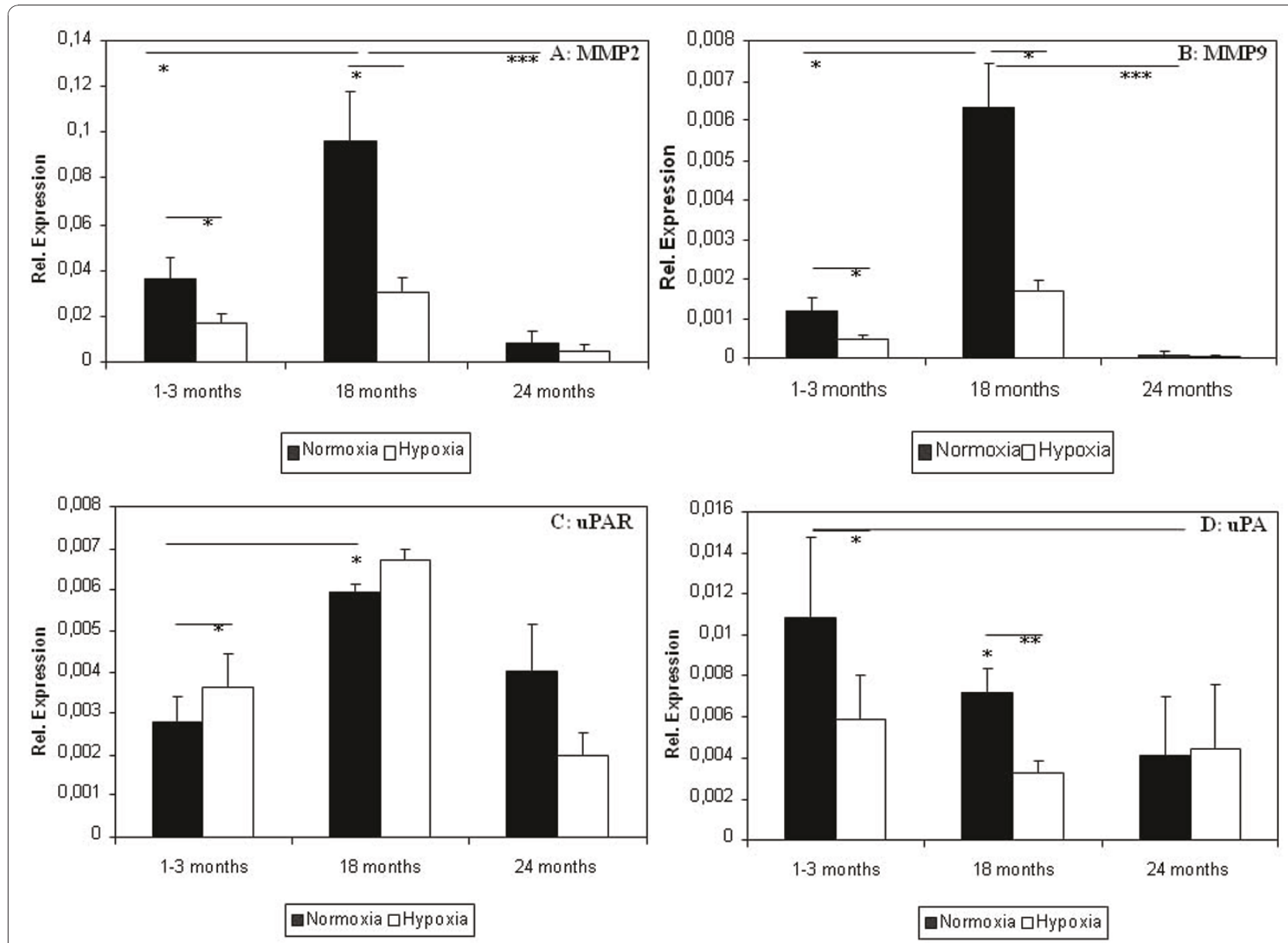

Figure 5 Effect of age and hypoxic stimulation on urokinase system factors gene expression. Expression levels of MMP2 (A), MMP9 (B), UPAR (C) and UPA (D) were measured using qRT-PCR. Animal groups consisted of young (1-3 month, 16 animals), aged (18 months, 9 animals) and old mice (24 months, 7 animals). Results are means of different animals $\left({ }^{*}=p<0.05,{ }^{* *}=p<0.01,{ }^{* *}=p<0.001\right.$ ).

can improve heart remodelling [51] or protect from limb ischemia [52]. MSC interact with endothelial cells and support the re-establishment of a blood supply, which is fundamental for tissue repair. Angiogenesis declines with age [53]. Therefore, we compared ADSC derived from young (1-3 months), adult (18 months) and aged ( 24 months old) mice in their ability to produce angiogenic growth factors.

We found that older ADSC showed impaired angiogenic properties in in vitro assays. VEGF and PlGF expression levels in young ADSC exceeded the corresponding levels in aged ADSC. Higher expression of VEGF was also observed in bone marrow derived MSC from young rats compared to 24-26 weeks old rats [23]. Decline of VEGF and TGFb expression as well as significant increase of anti-angiogenic factor TBS2 were found in (6 compared to 24 month) mice. This went along with decreased angiogenesis in these animals [54].
HGF expression increased in aged ADSC. This upregulation might be explained by a marked autocrine stimulation of ADSC by interleukin 1. Such a mechanism was demonstrated in fibroblasts derived from skin of aged donors [55].

Genes involved in matrix remodelling like uPAR, MMP 2 and MMP 9 were higher in ADSC from 18 month old mice. This point toward an enhanced invasive and migratory capacity of mature progenitors which has not been described before. In the oldest ADSC group, however it declined, which might be linked to impaired repair processes as found in many older organism.

Genes inhibiting angiogenesis like TBS1 and PAI-1 were up-regulated with age. ENDS did not follow this trend. Endostatin, a collagen degradation product, seems to counteract many VEGF induced effects including VEGF induced endothelial migration and neovascularisation [56]. Nothing is known about the age-related 

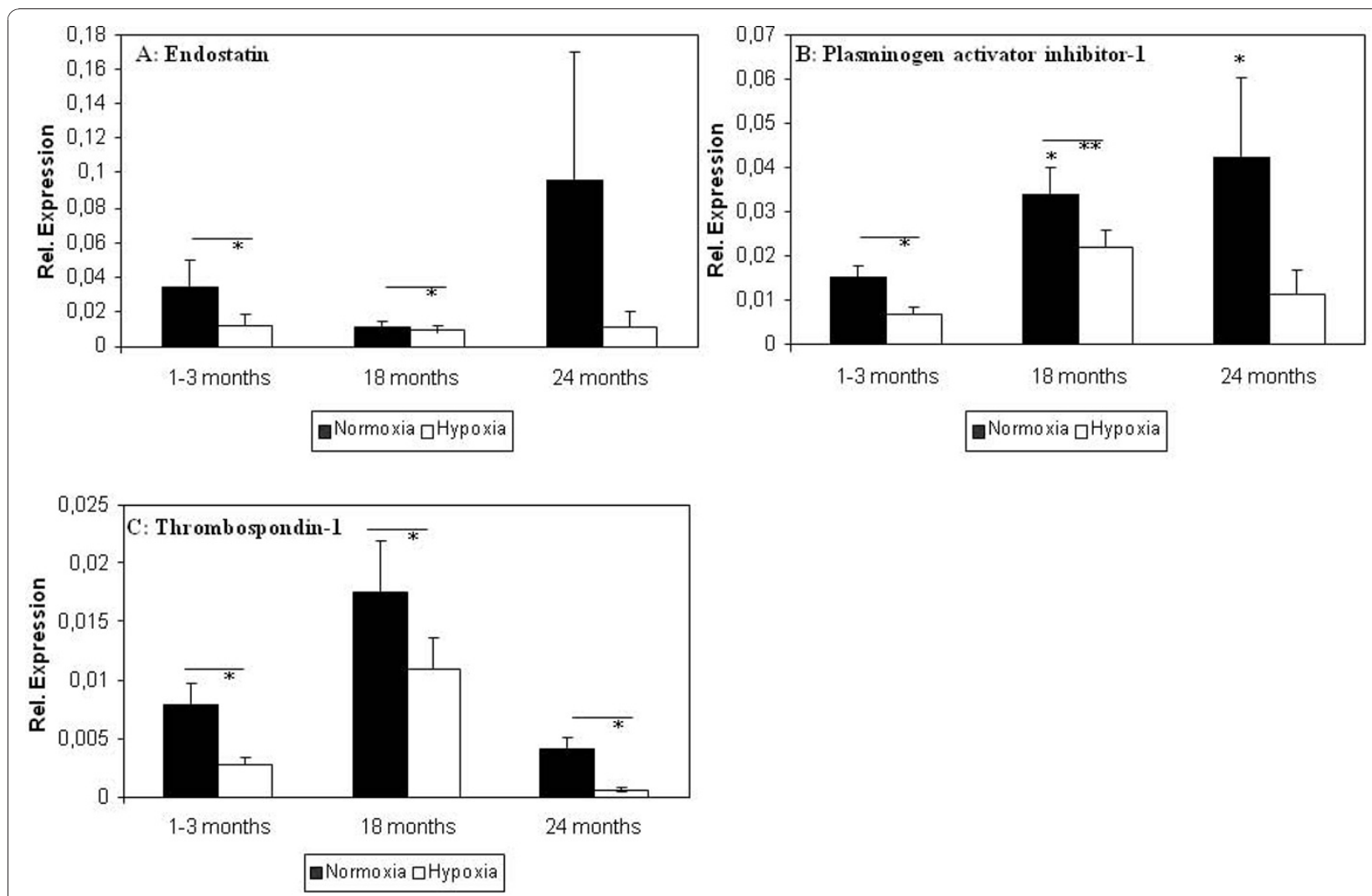

Figure 6 Effect of age and hypoxic stimulation on anti-angiogenic factors gene expression. Expression levels of ENDS (A), PAI (B) and TBS1 (C) were measured using qRT-PCR. Animal groups consisted of young (1-3 month, 16 animals), aged (18 months, 9 animals) and old mice (24 months, 7 animals). Results are means of different animals $\left(^{*}=p<0.05,{ }^{* *}=p<0.01,{ }^{* * *}=p<0.001\right.$ ).

\section{A: Tube assay: morphology}
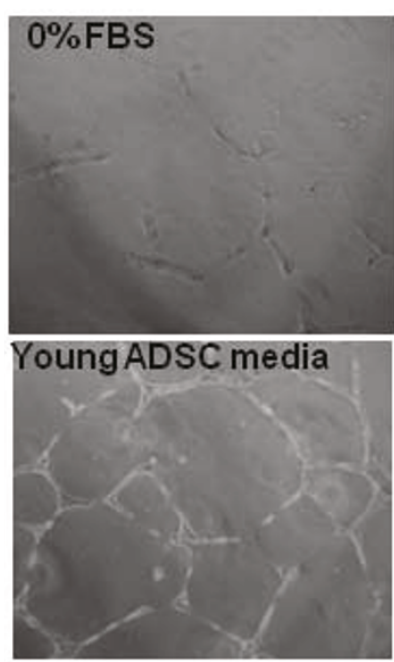
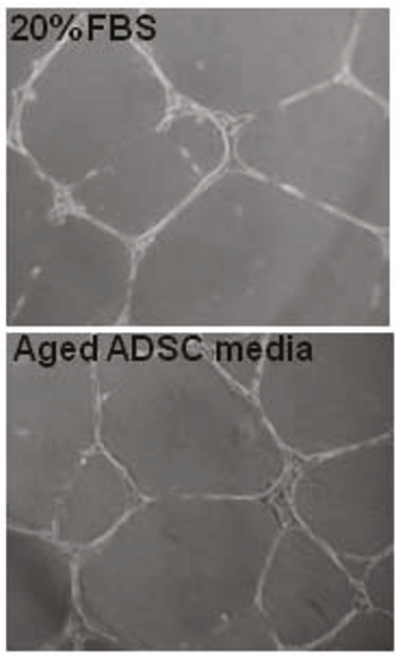

\section{B: Summary tube length}

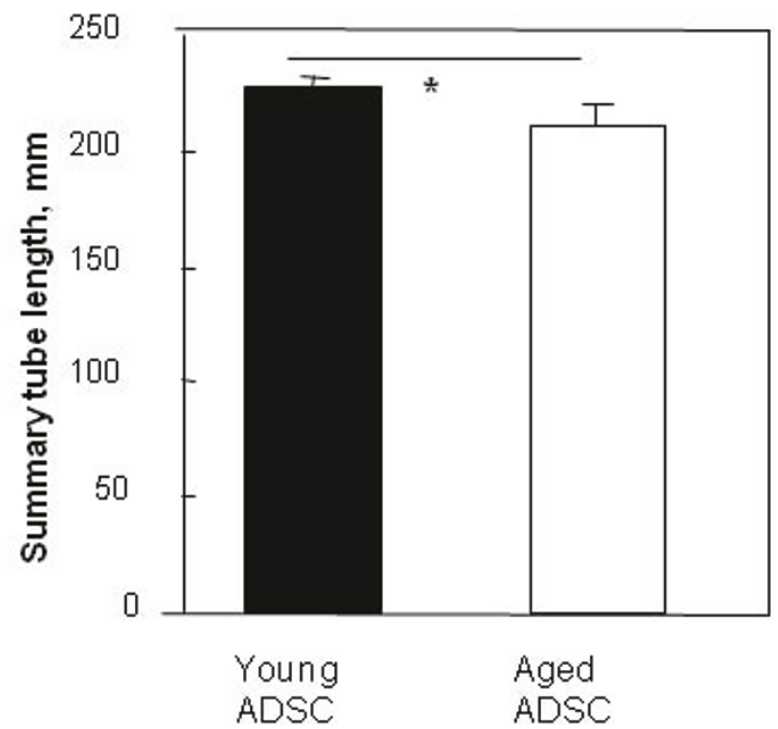

Figure 7 Effect of age and hypoxic stimulation on capillary-like tube formation in the presence of conditioned medium from ADSC. Morphology of tubes formed by endothelial cells on matrigel incubated with either medium alone, FBC containing medium or ADSC conditioned medium (A). Summary length of the formed tubes was quantified (B) $\left(^{*}=p<0.05\right)$. 
secretion of endostatin by mesenchymal stem cells. PAI-1 is a downstream target of p53 and is involved in regulating growth factor signalling [57]. In the liver and adipose tissues of rats PAI-1 was up-regulated in 24 month old rats compared to 3 month old rats [58]. An increase in PAI-1 was also found in senescent human fibroblasts [59].

TBS1, a microcellular protein and an autocrine factor for vascular smooth muscle cells, is constituently expressed in human MSC [60]. TBS-1 is up-regulated in the fibroblasts of 24 month old rats compared to 3 month old rats [61], which correlates with our results in mouse ADSC.

To check the angiogenic effect of the combination of factors secreted by ADSC we used an in vitro tube formation assay, which showed reduced tube formation in the presence of conditioned medium with secreted factors from aged ADSC. Similar results were obtained with bone marrow derived MSC [23] and for young human ADSC [62]. In these studies, however the difference was quite modest.

\section{Hypoxia and angiogenesis}

Tissue damage is often linked to ischemia. That is why it is important to understand the reaction of ADSC towards hypoxia but also because hypoxia can be used to stimulate MSC. Hypoxic conditioning of human ADSC can increase angiogenesis via secreted factors $[28,34,63]$, however nothing is known about this feature in ADSC derived from old donors. The most intensively studied mechanism of cell responses to hypoxia is HIF-1 alpha transcription factor activation. Activation of HIF-1 results in increased gene expression of angiogenesis stimulating factors such as VEGF, angiopoietin, PDGFB, $\mathrm{TGF} \beta_{1}$ and stromal derived factor 1 [64].

Grafting of hypoxia preconditioned bone marrow derived MSC improves their viability in damaged heart tissue and increases their capacity to stimulate blood vessel growth [65]. In addition hypoxia leads to enhanced MSC migration and formation of capillary-like structures in vitro [66].

No data on the effect of oxygen on the matrix remodelling genes uPAR and uPA in MSC from bone marrow are available. It was shown that gene expression of angiogenesis inhibitors including endostatin and PAI-1 were down-regulated in hypoxic human stromal cells [67] as it was found in our ADSC cells.

In summary, we found that hypoxia stimulated gene expression of pro-angiogenic factors and blocked gene expression of anti-angiogenic factors in ADSC. The effect was smaller in ADSC from older animals. Jiang et al. showed that bone marrow MSC from young rats were superior responders to anoxia both during the acute phase after exposure to anoxia and upon re-oxygenation for 48 hours compared to older rats [23]. Rivard et al. suggested that in aged donors impaired regulation of VEGF in response to hypoxia is due to declined hypoxia inducing factor 1 alpha activity [68].

\section{Conclusion}

Taken together our data shows that aged mice ADSC show impaired proliferation and stem cell characteristics, decreased angiogenic properties and a loss of stimulation by hypoxia suggest that short term hypoxic conditioning of ADSC is still effective in aged animals and might therefore be considered useful in therapies using MSC.

\section{Acknowledgements}

The study was supported by the DAAD providing a travel stipend, by the Fraunhofer Gesellschaft and by grants from Russian Federal Agency of Science and Innovation \#02.512.11.2287 and \#02.527.11.0007.

\section{Author details}

'Department of Biological and Medical Chemistry, Faculty of Fundamental Medicine, Lomonosov Moscow State University, Moscow, Russia. ${ }^{2}$ Fraunhofer Institute for Cell Therapy and Immunology, Leipzig, Germany.

\section{Authors' contributions}

$A E$ and $E S$ carried out the experimental studies and drafted the graphs. AE, AS and NK participated in the design of the study, performed the statistical analysis and wrote the paper. All authors read and approved the final manuscript.

\section{Competing interests}

The authors declare that they have no competing interests.

Received: 22 June 2010 Accepted: 18 January 2011

Published: 18 January 2011

\section{References}

1. Thomas ED: Bone marrow transplantation: prospects for leukemia and other conditions. Proc Inst Med Chic 1975, 30(8):256-258.

2. Bacigalupo A: Mesenchymal stem cells and haematopoietic stem cell transplantation. Best Pract Res Clin Haematol 2004, 17(3):387-399.

3. Kan I, Melamed E, Offen D: Integral therapeutic potential of bone marrow mesenchymal stem cells. Curr Drug Targets 2005, 6(1):31-41.

4. Shyu KG, Wang BW, Hung HF, Chang CC, Shih DT: Mesenchymal stem cells are superior to angiogenic growth factor genes for improving myocardial performance in the mouse model of acute myocardial infarction. J Biomed Sci 2005, 1-12.

5. Bieback K, Kern S, Kocaomer A, Ferlik K, Bugert P: Comparing mesenchymal stromal cells from different human tissues: bone marrow, adipose tissue and umbilical cord blood. Biomed Mater Eng 2008, 18(1 Suppl):S71-76.

6. Zuk PA, Zhu M, Ashjian P, De Ugarte DA, Huang Jl, Mizuno H, Alfonso ZC, Fraser JK, Benhaim P, Hedrick MH: Human adipose tissue is a source of multipotent stem cells. Mol Biol Cell 2002, 13(12):4279-4295.

7. Yamamoto N, Akamatsu H, Hasegawa S, Yamada T, Nakata S, Ohkuma M, Miyachi E, Marunouchi T, Matsunaga K: Isolation of multipotent stem cells from mouse adipose tissue. J Dermatol Sci 2007, 48(1):43-52.

8. Bujak M, Kweon HJ, Chatila K, Li N, Taffet G, Frangogiannis NG: Agingrelated defects are associated with adverse cardiac remodeling in a mouse model of reperfused myocardial infarction. J Am Coll Cardiol 2008, 51(14):1384-1392.

9. Sethe $S$, Scutt A, Stolzing A: Aging of mesenchymal stem cells. Ageing Res Rev 2006, 5(1):91-116.

10. Zuk PA, Zhu M, Mizuno H, Huang J, Futrell JW, Katz AJ, Benhaim P, Lorenz HP, Hedrick MH: Multilineage cells from human adipose tissue: implications for cell-based therapies. Tissue Eng 2001, 7(2):211-228. 
11. Strem BM, Hicok KC, Zhu M, Wulur I, Alfonso Z, Schreiber RE, Fraser JK, Hedrick $\mathrm{MH}$ : Multipotential differentiation of adipose tissue-derived stem cells. Keio J Med 2005, 54(3):132-141.

12. Schaffler A, Buchler $C$ : Concise review: adipose tissue-derived stromal cells-basic and clinical implications for novel cell-based therapies. Stem Cells 2007, 25(4):818-827.

13. De Ugarte DA, Alfonso Z, Zuk PA, Elbarbary A, Zhu M, Ashjian P, Benhaim P, Hedrick MH, Fraser JK: Differential expression of stem cell mobilizationassociated molecules on multi-lineage cells from adipose tissue and bone marrow. Immunol Lett 2003, 89(2-3):267-270.

14. Boquest AC, Shahdadfar A, Fronsdal K, Sigurjonsson O, Tunheim SH, Collas $P$, Brinchmann JE: Isolation and transcription profiling of purified uncultured human stromal stem cells: alteration of gene expression after in vitro cell culture. Mol Biol Cell 2005, 16(3):1131-1141.

15. Fraser JK, Wulur I, Alfonso Z, Hedrick MH: Fat tissue: an underappreciated source of stem cells for biotechnology. Trends Biotechnol 2006, 24(4):150-154.

16. Kang SK, Jun ES, Bae YC, Jung JS: Interactions between human adipose stromal cells and mouse neural stem cells in vitro. Brain Res Dev Brain Res 2003, 145(1):141-149.

17. Cowan CM, Shi YY, Aalami OO, Chou YF, Mari C, Thomas R, Quarto N, Contag CH, Wu B, Longaker MT: Adipose-derived adult stromal cells heal critical-size mouse calvarial defects. Nat Biotechnol 2004, 22(5):560-567.

18. Cousin B, Andre M, Arnaud E, Penicaud L, Casteilla L: Reconstitution of lethally irradiated mice by cells isolated from adipose tissue. Biochem Biophys Res Commun 2003, 301(4):1016-1022.

19. Murohara T, Shintani S, Kondo K: Autologous adipose-derived regenerative cells for therapeutic angiogenesis. Curr Pharm Des 2009, 15(24):2784-2790.

20. Meza-Zepeda LA, Noer A, Dahl JA, Micci F, Myklebost O, Collas P: Highresolution analysis of genetic stability of human adipose tissue stem cells cultured to senescence. J Cell Mol Med 2008, 12(2):553-563.

21. Noer A, Boquest AC, Collas P: Dynamics of adipogenic promoter DNA methylation during clonal culture of human adipose stem cells to senescence. BMC Cell Biol 2007, 8:18.

22. Rubio D, Garcia-Castro J, Martin MC, de la Fuente R, Cigudosa JC, Lloyd AC, Bernad A: Spontaneous human adult stem cell transformation. Cancer Res 2005, 65(8):3035-3039.

23. Jiang $S$, Kh Haider $H$, Ahmed RP, Idris NM, Salim A, Ashraf M: Transcriptional profiling of young and old mesenchymal stem cells in response to oxygen deprivation and reparability of the infarcted myocardium. J Mol Cell Cardiol 2008, 44(3):582-596.

24. Zscharnack M, Poesel C, Galle J, Bader A: Low oxygen expansion improves subsequent chondrogenesis of ovine bone-marrow-derived mesenchymal stem cells in collagen type I hydrogel. Cells Tissues Organs 2009, 190(2):81-93.

25. Fehrer $C$, Brunauer $R$, Laschober $G$, Unterluggauer $H$, Reitinger $S$, Kloss $F$, Gully C, Gassner R, Lepperdinger G: Reduced oxygen tension attenuates differentiation capacity of human mesenchymal stem cells and prolongs their lifespan. Aging Cell 2007, 6(6):745-757.

26. Gennaro G, Menard C, Michaud SE, Rivard A: Age-dependent impairment of reendothelialization after arterial injury: role of vascular endothelial growth factor. Circulation 2003, 107(2):230-233.

27. Weinsaft JW, Edelberg JM: Aging-associated changes in vascular activity: a potential link to geriatric cardiovascular disease. Am J Geriatr Cardiol 2001, 10(6):348-354.

28. Rehman J, Traktuev D, Li J, Merfeld-Clauss S, Temm-Grove CJ, Bovenkerk JE, Pell CL, Johnstone BH, Considine RV, March KL: Secretion of angiogenic and antiapoptotic factors by human adipose stromal cells. Circulation 2004, 109(10):1292-1298.

29. Kondo K, Shintani S, Shibata R, Murakami H, Murakami R, Imaizumi M, Kitagawa $Y$, Murohara T: Implantation of adipose-derived regenerative cells enhances ischemia-induced angiogenesis. Arterioscler Thromb Vasc Biol 2009, 29(1):61-66.

30. Gimble JM, Katz AJ, Bunnell BA: Adipose-derived stem cells for regenerative medicine. Circ Res 2007, 100(9):1249-1260.

31. Nakagami H, Maeda K, Morishita R, Iguchi S, Nishikawa T, Takami $Y$, Kikuchi Y, Saito Y, Tamai K, Ogihara T, et al: Novel autologous cell therapy in ischemic limb disease through growth factor secretion by cultured adipose tissue-derived stromal cells. Arterioscler Thromb Vasc Biol 2005, 25(12):2542-2547.
32. Madonna R, De Caterina R: Adipose tissue: a new source for cardiovascular repair. J Cardiovasc Med (Hagerstown) 2010, 11(2):71-80.

33. Rubina K, Kalinina N, Efimenko A, Lopatina T, Melikhova V, Tsokolaeva Z, Sysoeva V, Tkachuk V, Parfyonova Y: Adipose stromal cells stimulate angiogenesis via promoting progenitor cell differentiation, secretion of angiogenic factors, and enhancing vessel maturation. Tissue Eng Part $A$ 2009, 15(8):2039-2050.

34. Efimenko A, Starostina EE, Rubina KA, Kalinina NI, Parfenova EV: Viability and angiogenic activity of mesenchymal stromal cells from adipose tissue and bone marrow in hypoxia and inflammation in vitro. Tsitologiia 2010, 52(2):144-154.

35. Ohnishi S, Yasuda T, Kitamura S, Nagaya N: Effect of hypoxia on gene expression of bone marrow-derived mesenchymal stem cells and mononuclear cells. Stem Cells 2007, 25(5):1166-1177.

36. Potier E, Ferreira E, Andriamanalijaona R, Pujol JP, Oudina K, LogeartAvramoglou D, Petite H: Hypoxia affects mesenchymal stromal cell osteogenic differentiation and angiogenic factor expression. Bone 2007, 40(4):1078-1087

37. Dennis JE, Caplan Al: Analysis of the developmental potential of conditionally immortal marrow-derived mesenchymal progenitor cells isolated from the $\mathrm{H}-2 \mathrm{~Kb}$-tsA58 transgenic mouse. Connect Tissue Res 1996, 35(1-4):93-99.

38. Cawthon RM: Telomere measurement by quantitative PCR. Nucleic Acids Res 2002, 30(10):e47

39. Buss H, Chan TP, Sluis KB, Domigan NM, Winterbourn CC: Protein carbonyl measurement by a sensitive ELISA method. Free Radic Biol Med 1997, 23(3):361-366.

40. Sitte N, Merker K, Grune T: Proteasome-dependent degradation of oxidized proteins in MRC-5 fibroblasts. FEBS Lett 1998, 440(3):399-402.

41. Dominici M, Le Blanc K, Mueller I, Slaper-Cortenbach I, Marini F, Krause D, Deans R, Keating A, Prockop D, Horwitz E: Minimal criteria for defining multipotent mesenchymal stromal cells. The International Society for Cellular Therapy position statement. Cytotherapy 2006, 8(4):315-317.

42. Zannettino AC, Paton S, Arthur A, Khor F, Itescu S, Gimble JM, Gronthos S: Multipotential human adipose-derived stromal stem cells exhibit a perivascular phenotype in vitro and in vivo. J Cell Physiol 2008, 214(2):413-421.

43. Traktuev DO, Merfeld-Clauss S, Li J, Kolonin M, Arap W, Pasqualini R, Johnstone BH, March KL: A population of multipotent CD34-positive adipose stromal cells share pericyte and mesenchymal surface markers, reside in a periendothelial location, and stabilize endothelial networks. Circ Res 2008, 102(1):77-85.

44. Stolzing A, Jones E, McGonagle D, Scutt A: Age-related changes in human bone marrow-derived mesenchymal stem cells: consequences for cell therapies. Mech Ageing Dev 2008, 129(3):163-173.

45. Zhou S, Greenberger JS, Epperly MW, Goff JP, Adler C, Leboff MS, Glowacki J: Age-related intrinsic changes in human bone-marrowderived mesenchymal stem cells and their differentiation to osteoblasts. Aging Cell 2008, 7(3):335-343.

46. Mallette FA, Gaumont-Leclerc MF, Huot G, Ferbeyre G: Myc downregulation as a mechanism to activate the Rb pathway in STAT5Ainduced senescence. J Biol Chem 2007, 282(48):34938-34944.

47. Carlson ME, Conboy MJ, Hsu M, Barchas L, Jeong J, Agrawal A, Mikels AJ, Agrawal S, Schaffer DV, Conboy IM: Relative roles of TGF-beta1 and Wnt in the systemic regulation and aging of satellite cell responses. Aging Cell 2009, 8(6):676-689.

48. Baxter MA, Wynn RF, Jowitt SN, Wraith JE, Fairbairn LJ, Bellantuono I: Study of telomere length reveals rapid aging of human marrow stromal cells following in vitro expansion. Stem Cells 2004, 22(5):675-682.

49. Stolzing A, Sethe S, Scutt AM: Stressed stem cells: Temperature response in aged mesenchymal stem cells. Stem Cells Dev 2006, 15(4):478-487.

50. Caplan Al, Dennis JE: Mesenchymal stem cells as trophic mediators. J Cell Biochem 2006, 98(5):1076-1084.

51. Stamm C, Westphal B, Kleine HD, Petzsch M, Kittner C, Klinge $H$ Schumichen C, Nienaber CA, Freund M, Steinhoff G: Autologous bonemarrow stem-cell transplantation for myocardial regeneration. Lancet 2003, 361(9351):45-46.

52. Ishikane S, Ohnishi S, Yamahara K, Sada M, Harada K, Mishima K, Iwasaki K, Fujiwara M, Kitamura S, Nagaya N, et al: Allogeneic injection of fetal membrane-derived mesenchymal stem cells induces therapeutic 
angiogenesis in a rat model of hind limb ischemia. Stem Cells 2008, 26(10):2625-2633.

53. Reed MJ, Edelberg JM: Impaired angiogenesis in the aged. Sci Aging Knowledge Environ 2004, 2004(7):pe7.

54. Sadoun E, Reed MJ: Impaired angiogenesis in aging is associated with alterations in vessel density, matrix composition, inflammatory response, and growth factor expression. J Histochem Cytochem 2003, 51(9):1119-1130.

55. Miyazaki M, Gohda E, Kaji K, Namba M: Increased hepatocyte growth factor production by aging human fibroblasts mainly due to autocrine stimulation by interleukin-1. Biochem Biophys Res Commun 1998, 246(1):255-260.

56. O'Reilly MS, Boehm T, Shing Y, Fukai N, Vasios G, Lane WS, Flynn E, Birkhead JR, Olsen BR, Folkman J: Endostatin: an endogenous inhibitor of angiogenesis and tumor growth. Cell 1997, 88(2):277-285.

57. Kortlever RM, Higgins PJ, Bernards R: Plasminogen activator inhibitor- 1 is a critical downstream target of p53 in the induction of replicative senescence. Nat Cell Biol 2006, 8(8):877-884

58. Serrano R, Barrenetxe J, Orbe J, Rodriguez JA, Gallardo N, Martinez C, Andres A, Paramo JA: Tissue-specific PAl-1 gene expression and glycosylation pattern in insulin-resistant old rats. Am J Physiol Regul Integr Comp Physiol 2009, 297(5):R1563-1569.

59. Wang S, Moerman EJ, Jones RA, Thweatt R, Goldstein S: Characterization of IGFBP-3, PAI-1 and SPARC mRNA expression in senescent fibroblasts. Mech Ageing Dev 1996, 92(2-3):121-132.

60. Oh JY, Kim MK, Shin MS, Wee WR, Lee JH: Cytokine secretion by human mesenchymal stem cells cocultured with damaged corneal epithelial cells. Cytokine 2009, 46(1):100-103.

61. Olson BA, Day JR, Laping NJ: Age-related expression of renal thrombospondin 1 mRNA in F344 rats: resemblance to diabetes-induced expression in obese Zucker rats. Pharmacology 1999, 58(4):200-208.

62. Madonna R, De Caterina R: In vitro neovasculogenic potential of resident adipose tissue precursors. Am J Physiol Cell Physiol 2008, 295(5): C1271-1280.

63. Weil BR, Markel TA, Herrmann JL, Abarbanell AM, Meldrum DR: Mesenchymal stem cells enhance the viability and proliferation of human fetal intestinal epithelial cells following hypoxic injury via paracrine mechanisms. Surgery 2009, 146(2):190-197.

64. Ruas JL, Lendahl U, Poellinger L: Modulation of vascular gene expression by hypoxia. Curr Opin Lipidol 2007, 18(5):508-514.

65. Hu X, Yu SP, Fraser JL, Lu Z, Ogle ME, Wang JA, Wei L: Transplantation of hypoxia-preconditioned mesenchymal stem cells improves infarcted heart function via enhanced survival of implanted cells and angiogenesis. J Thorac Cardiovasc Surg 2008, 135(4):799-808.

66. Annabi B, Lee YT, Turcotte S, Naud E, Desrosiers RR, Champagne M, Eliopoulos N, Galipeau J, Beliveau R: Hypoxia promotes murine bonemarrow-derived stromal cell migration and tube formation. Stem Cells 2003, 21(3):337-347.

67. Nasu K, Nishida M, Fukuda J, Kawano Y, Nishida Y, Miyakawa I: Hypoxia simultaneously inhibits endostatin production and stimulates vascular endothelial growth factor production by cultured human endometrial stromal cells. Fertil Steril 2004, 82(3):756-759.

68. Rivard A, Berthou-Soulie L, Principe N, Kearney M, Curry C, Branellec D, Semenza GL, Isner JM: Age-dependent defect in vascular endothelial growth factor expression is associated with reduced hypoxia-inducible factor 1 activity. J Biol Chem 2000, 275(38):29643-29647.

doi:10.1186/1479-5876-9-10

Cite this article as: Efimenko et al.: Angiogenic properties of aged adipose derived mesenchymal stem cells after hypoxic conditioning. Journal of Translational Medicine 2011 9:10.

\section{Submit your next manuscript to BioMed Central and take full advantage of:}

- Convenient online submission

- Thorough peer review

- No space constraints or color figure charges

- Immediate publication on acceptance

- Inclusion in PubMed, CAS, Scopus and Google Scholar

- Research which is freely available for redistribution

Submit your manuscript at www.biomedcentral.com/submit
Biomed Central 